\title{
Stage III Renal Cell Cancer AJCC v8
}

National Cancer Institute

\section{Source}

National Cancer Institute. Stage III Renal Cell Cancer A/CC v8. NCI Thesaurus. Code C140325.

Stage III includes: (T1, N1, M0); (T2, N1, M0); (T3, N0, M0); (T3, N1, M0). T1: Tumor measuring $7 \mathrm{~cm}$ or less in greatest dimension, limited to the kidney. T2: Tumor measuring more than $7 \mathrm{~cm}$ in greatest dimension, limited to the kidney. T3: T umor extending into major veins or perinephric tissues, but not into the ipsilateral adrenal gland and not beyond Gerota's fascia. N0: No regional lymph node metastasis. N1: Metastasis in regional lymph node(s). M0: No distant metastasis. (AJCC 8th ed.) 